\title{
THE SACRED GROVES OF THE CURONIAN KONINI: PAST AND PRESENT
}

\author{
Sandis Laime
}

\begin{abstract}
The current article deals with the reflection of the holy groves of the so-called Curonian ķoniņi (kuršu ķoniņi) in historical sources and contemporary folklore. The Curonian ksonini constituted a special estate of freemen who enjoyed the same status as other vassals of the Livonian Order in Courland.

On the one hand, there is quite a rich collection of written evidence concerning the holy groves of the Ķoninini, possibly dating even from 1414. On the other hand, there is a vivid contemporary oral tradition concerning the holy grove of one of the villages of ķoniņi - Ķoniņi Elka Grove. Both sources have been examined in the article in order to find out the reasons for the atypically strong local oral tradition concerning the holy grove and the motives used in the stories told about the grove.
\end{abstract}

Key words: Curonian ķ̧oniņi, holy groves, medieval travel notes, sacred places of the Balts

\section{THE CURONIAN K, KONIN,I}

The history of law in Latvia includes examples where, after the subjugation of the local tribes in the 13 th century, certain families among the conquered tribes became vassals of the order. The most vivid example is that of the Curonian ksoniñi, who inhabited seven villages in the Kuldīga area: Koniņi, Ziemel̦i, Kalêji, Pliksi, Dragūni, Viesalgi and Sausgal̦i. The Curonian ksoniņi were neither peasants, nor free peasants, but instead constituted a special estate of freemen, to whom the peasant laws of Courland did not apply and who enjoyed the same status as other vassals of the order in Courland. The lands of the konini were exempt from census payment and from labour duties. They differed from the estate-holders in that they had no estates or peasants. On the other hand, like the estate-holders, the konini enjoyed hunting, fishing and milling rights, and, like the knights, they had their own coats of arms. In terms of jurisdiction, too, the Curonian ksoninni were equated to the estate-holders, since up to 1561 their cases were tried by the order's commander in Kuldīga. Over the course of time, the rights of the ksonini were gradually taken from them, but after a 74year legal struggle, from 1810 up to 1884 all their rights and privileges were 
restored. The last specific historical characteristics of the Curonian ksonini were eliminated in 1929, when the Parliament of the Republic of Latvia (Saeima) passed the Law on the Division of the Free Villages of Kuldigga County into Single Farmsteads (Švābe 1934). Nowadays, for various reasons, the villages of the Curonian ksoninin have either been abandoned (e.g., the village of Pliki) for a variety of reasons (land improvement work in the years of Soviet power, or fires), or else only a few farms remain in the villages, while the descendants of the ķoniņi families (Tontegode, Peniķis, Šmits, Vidin̄š, and others) have become dispersed throughout Latvia or have emigrated in connection with the events of the Second World War.

In research conducted by the Baltic Germans, there were two opposed views on the origin of the term 'Curonian ksonini' (literally 'Curonian kings'), which is first mentioned in written sources in 1504. Historian Arveds Švābe presents arguments in support of the view that at least two of the konini families are descended from the ancient Curonian rulers, an idea that is indeed backed up by various facts (Švābe 1934: 19067). In the first place, the four ksoninzi villages in Turlava parish (Ķoniņi, Pliķi, Kalēji, and Ziemelii) cover an undivided area of 1,852 hectares, whose extent testifies to the existence of an ancient district ruled over by a lord. Secondly, it is significant that all four villages lie close to Lipaiki Hillfort ${ }^{1}$ and to Ķonini's Elka Grove (Elku birzs or simply Elka is located a couple of kilometres from the hillfort), which could have been the cult site corresponding to the hillfort. ${ }^{2}$ In other words, the later free villages were located at an earlier administrative centre (the hillfort) and religious centre (the holy grove). Thirdly, there is the etymology of the family name of the elder of Pliķi village - Tontegode. The name is clearly not of Latvian origin. Švābe sees it as a compound word that he tries to connect with words having a Scandinavian root [Swedish tomte, from which derive the Finnish tonttu and Estonian tont 'domestic spirit' and the Old Norse godi 'a priest or little lord' (Švābe 1934: 19067)], concluding that "presumably, the Tontegode now living in Turlava parish once owned the sacred Elka Place" (Švābe 1933: 32). The name of Tontegode is first mentioned in a feudal charter of 1320 .

Although assumptions of Švābe could have been influenced by the idealistic National-Romantic research tendencies of that period, his opinion is being quoted also by contemporary Latvian historians (e.g., Auns 1995).

Although the descendants of the ancient Curonian rulers lost their political power when the order took over Courland, they retained their freedoms, partially acquired the characteristic rights and privileges of the German vassals, and for several centuries, although formally Christian, maintained some of their pagan Curonian practices. 


\section{THE SACRED GROVES OF THE CURONIAN ĶONIN̦I}

There are three known holy groves associated with the seven konini villages of the Kuldigga area (Fig. 1). At the present day, the best-known of these is the Konini Elka Grove (Kurtz 1924: 78), which is protected as an archaeological monument of national importance. It can be said with a high degree of confidence that this clump of trees and bushes, covering about one hectare, was a much larger forest in the past. The ancient name of the grove - Elku birzs ('Elka Grove') or simply Elka - is also preserved up to the present day. In a couple of sources, Elkas / Elka kalns ('Elka Hill') is mentioned in the vicinity of Konini village. ${ }^{3}$ Presumably, this is the same Elka Grove, the remains of which nowadays occupy the top of the highest hill in the area. That the Elka Grove was formerly more extensive is suggested by the place name Elku plava ('Elka Meadow'), ${ }^{4}$ mentioned in Turlava parish. In the course of fieldwork in 2006, it was established that there had been a meadow by this name at the river Riva, about 1.5 kilometres from the present Elka Grove. It is possible that the location of the meadow was formerly covered by the holy forest, as a result of which the meadow created in later times has retained the ancient name. Since the Elka Grove is surrounded on three sides by the villages of Ķonini, Kalejji, and Ziemeli (see the map, Fig. 1), it may be thought that this was a holy grove common to all three villages.

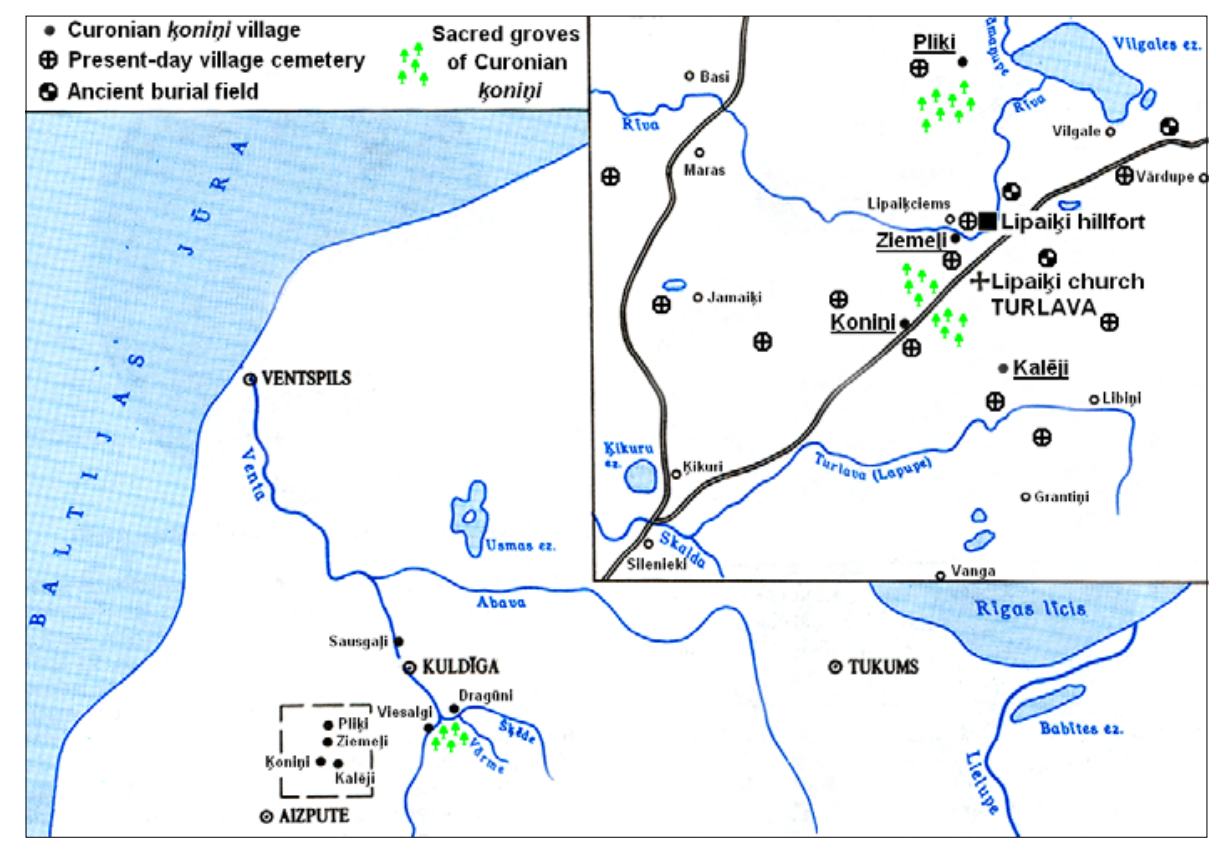

Figure 1. Konini villages and their holy groves (Auns 1995: 28, improved by Sandis Laime). 
Already from the early 16 th century, written sources mention a holy grove at the village of Dragūni (Kurtz 1924: 77). It is located on the banks of the Eda, a right tributary of the Venta, near to the mouth of the stream. ${ }^{5}$ On the left bank of the Venta there was another konini village - Viesalgi. Although the lands of Viesalgi were mostly located on the left bank of the Venta, a small part of the territory extended to the opposite bank of the Venta, that is, to the area of the holy grove, thus also giving Viesalgi access to the holy grove. Thus, the forest can be regarded as a holy forest of both villages, Dragūni and Viesalgi (Dunsdorfs 1975: 46).

It is thought that there was also a holy grove not far from the cemetery of Pliki in Turlava parish. The village itself is no longer in existence. In 2006, Austra Tontegode, a former inhabitant of the village and a descendant of the koninni family, told of the holy grove near the village of Pliki during a field study by the Faculty of Philology of the University of Latvia in 2006. She had learned about the grove from her father, who had called it Elku birzs ('Elka Grove') and had said that one should not break the branches of trees there. At the same time, Austra Tontegode added that this prohibition was not as categorical as that pertaining to the Konini's Elka Grove. Citing the place name evidence collected by August Bielenstein, Edith Kurtz mentions an 'Elka Hill' near Pliķi village in her account of cult sites in Latvia (Kurtz 1924: 78). It is possible that, as in the case of the site near Konini, the Elka Hill and Elka Grove are in fact one and the same place.

\section{EVIDENCE FROM HISTORICAL SOURCES REGARDING THE HOLY GROVES OF THE CURONIAN ĶONINI}

It is possible that the first mention in written sources of the Konini Elka Grove occurs in the record left by the French knight Guillebert de Lannoy in 1414. In 1413-1414 he travelled through Livonia, and has left a short description of a Curonian funeral in his travel notes:

The aforementioned Curonians, although they have been made Christian by force, have a sect that, instead of burying their dead, burns them in a nearby grove or forest, dressed and adorned with the finest ornaments, constructing a pyre entirely from oak wood; and they consider that if the smoke rises straight up to the heavens, then the soul is saved, but if it is blown to the side, then the soul is lost (quoted after Šturms 1948: 19).

Although the text does not refer to any specific location, in the view of historian Edgars Dunsdorfs, the funeral procession described by Lannoy was wit- 
nessed by him among the konini, when he took part in the funeral of Curonian kুoniņš Penikis. There are several clues that support this idea. In the first place, since Lannoy was travelling from Grobina to Kuldīga, he had to travel through Koninni village. This was the only Curonian ķoningi village that was, and still is, located next to the highway. Secondly, in the description of his travels, Lannoy generally does not describe anything other than the places that he visited, and the description of the Curonian funeral is one of the few fragments describing his observations during his travels, and so we may conclude that Lannoy himself witnessed the funeral ceremony, and that what he saw left a big impression on him. Thirdly, it is only in the free villages of the konini that the ancient traditions could still be observed being practiced so openly in the early 15 th century, since they were actively combated by the Christian Church (Dunsdorfs 1956: 74-75). Thus, if Lannoy did take part in a Curonian ksonini funeral, he is most likely to have witnessed the cremation at the Konini Elka Grove.

The first definite written evidence of the konini holy groves dates from 20 December 1503, when Wolter von Plettenberg, Master of the Livonian Order, granted a fief of two hides in Kuldīga District to the Curonian ķoniņš Dragūns and his true heirs. The first point mentioned in the description of the boundaries of the fief is the holy grove Elkewalke:

twe hakenn landes im gebede unnd kerspel to Goldingen in dusser nagescreven schedung gelegenn: interste antogaende an enen hilligen busche, genomet Elkewalke, van deme busche recht togande an enen berch, genomet Viteskaln, van deme berge an enen sype, genomet Surewalke, dem sypen to folgend an ene becke, genomet Edesuppe, der becke to folgende in de Winda... (quoted after Dunsdorfs 1975: 44).

[two hides of land in the district and church parish of Kuldīga within the following boundaries: from the holy grove known as Elkavalks, directly to the hill called Viteskalns, from this hill to the stream called Surevalks, along the stream to the river known as Ėdasupe, and along the river to the Venta...]

Assuming that the boundary follows the direction of the sun's passage, which was the general practice at the time, and that the boundary description is closed, that is, the last point is close to the first, Dunsdorfs concludes that Elkvalks could be a grove in the holy forest of Vārma on the bank of the river Eda near the river Venta (Dunsdorfs 1975: 44).

The name of the holy forest recorded in the boundary description, Elkewalke, is a compound, the second part of which consists of the geographic term valks, which in Kurzeme is generally understood to mean a small stream (Bušs 2004). The word valks is also used in this sense in the same boundary description, namely with reference to the stream called Surewalke. Elkvalks is also the 


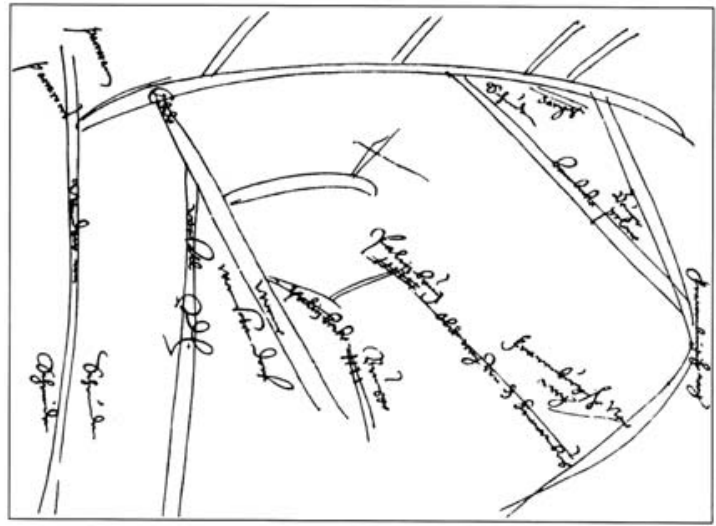

Figure 2. Topographic plan of the holy forest of Draguni from the Swedish State Archives (late 15th or early 16th century) (after Dunsdorfs 1975).

has been applied in the boundary description to the forest through which it flowed.

The holy forest of Vārma, which still exists next to Dragūni in the present day, is also shown in a topographic plan that Edgars Dunsdorfs found in the Swedish State Archives (Livonica I, 50) (Fig. 2). Judging from this handwritten plan, it dates from the late 15th or early 16th century (Dunsdorfs 1975: 43). The fact that a plan has been made specifically of Vārma forest clearly indicates its particular significance, and so, in view of the mention of the holy grove of Elkvalks in the 1503 description of the boundary of the Dragūns fief, Dunsdorfs has advanced the hypothesis that the plan shows one of the holy forests of the koninin (Dunsdorfs \& Spekke 1964: 232-233, Dunsdorfs 1975). It is significant that the Saldus-Kuldiga road, which nowadays passes through the forest, passed around that forest at the time when the plan was made, thus safeguarding the trees and animals of the holy forest.

Very important for understanding the traditions connected with the holy forests of the ksoniņi is a travel description by Königsberg apothecary Reinhold Lubenau, who left Königsberg for Riga on 20 December 1585:

I first reached Mummel and then passed through Courland, reaching the Curonian king, where we had to watch his pagan superstitions. Since Christmas was approaching, they went hunting in their holy forest, where they do no hunting and do not cut a single rod throughout the rest of the year. All that they now hunted there: roe deer, red deer and hares, they skinned, cooked and placed on a long table. They fastened a large number of wax candles to the table, for the souls of their parents, children and relatives. After this, standing and walking to and fro, they ate and drank, and forced us to do likewise. Later, they brought an empty beer keg and beat on it with two sticks, and the men and women, as well as the children, danced around the table, something that continued for the whole night. When they went to bed one after another, they invited us to eat 
and take with us what we would, since they would not eat what was left over, but would give it to the dogs. Neither did they want to take any payment from us for what we had eaten (quoted after Šturms 1948: 20).

Although Lubenau does not specify in which of the Curonian koningi villages he witnessed this ritual in memory of the dead, the description is usually mentioned as connected with the Koniņi Elka Grove in Turlava parish (see, e.g., Šturms 1948: 20; Urtāns 1993: 20ff).

The next piece of evidence, too, may relate to Ķonini Elka Grove. In 1678, the Curonian ksoningi donated a bell to Lipaiki Church, with a hunting scene on the rim, where ksonini dressed in festive dress chase hares and wolves on horseback holding spears and with dogs on leashes (Kampe 1930: 110). ${ }^{6}$ Four konini villages belonged to the church parish of Lipaiķi: Kalēji, Ziemel̦i, Ķonini and Pliki. In the opinion of Dunsdorfs, the rim of the bell shows the koningi hunting in the holy forest, indicating the importance of the tradition of the konini holy forest as late as in the 17th century (Dunsdorfs 1975: 46). It does rather seem, however, that the bell shows an ordinary hunting scene, since, judging from Lubenau's account, the ksonini went hunting in their holy forest only once a year, to provide game for the memorial feast for the dead ("roe deer, red deer and hares"), but the hunting scene on the rim of the bell shows the hunters chasing not only hares, but also wolves. It is doubtful whether wolf was a suitable dish for a feast in honour of the dead. The hunting scene on the rim of the bell may rather be seen as an expression of konini pride, since by this means they were creating a reminder of their hunting privileges, rights that other Latvian peasants did not have.

Written evidence of the holy groves of the konini is also preserved from the early 18 th century. This is the record left by traveller J. Kanold, describing a holy forest near a Curonian konini village, where they never dare to touch the trees and where they observe a feast of the dead at Midsummer (Kurtz 1924: 78).

Bringing together the written evidence, we may conclude that:

- Compared with other ancient cult sites in Latvia, there is quite a rich collection of written evidence concerning the holy groves of the ksonini, dating back at least to 1503 (possibly even to 1414);

- At the present day, the names of all the holy forests of the ksonini include the root elk-, which is a characteristic word that denotes ancient Baltic sacred places (Straubergs 1960: 146-147; Urtāns 1998: 23; Vaitkevičius 2003: 21-23, etc.). In the written sources, this root is first recorded in the name of the holy forest of Dragūni in 1503;

- The prohibition against harming the trees and animals of the holy forest in any way without ritual necessity was first mentioned in 1585 and 
reaffirmed in the early 18th century; such a prohibition regulating human behaviour with respect to holy groves and trees is very widespread in Latvia and beyond its borders;

- The written sources testify to a close connection between the holy forests and the cult of the dead. They generally support the hypothesis advanced by Eduards Šturms that "the holy forests were initially burial sites, then places for the cult of the dead and the ancestors, and finally cult sites dedicated to the gods" (Šturms 1948: 21). The establishment of burial sites in the holy forests remains to be proven archaeologically, although it seems more likely, and this seems to be suggested by Lannoy's account, that the ancient cemeteries were located near the holy groves, where cremation was carried out. ${ }^{7}$ The practice of cremating the dead in some cases continued among the Curonians right up to the early 15th century (Mugurēvičs 1999: 57), after which the holy forests lost their function as crematoria, retaining another function, aptly formulated by Šturms: "the holy forests were places reserved for the dead, their inviolable property, from which materials were obtained at least for the needs of the memorial cult" (Šturms 1948: 20). The free villages of the ksonini might also be described as reserves, since in this closed community, ${ }^{8}$ thanks to their historically determined social position and various privileges, the Curonian koninini could much more easily maintain the traditions of their ancestors, including those that related to the holy forests. In the next chapter, we will discuss the handing down of the tradition and the presence of the Koniņi Elka Grove in contemporary oral tradition.

\section{FOLKLORE EVIDENCE CONCERNING THE ĶONIN̦I ELKA GROVE}

The wide range of historical sources relating to Konini Elka Grove begs the question: what remains of the ancient beliefs and traditions in the 20th and 21 st century? We can obtain a partial answer to this question by investigating the folklore material.

The Archives of Latvian Folklore contain a small number of texts relating to Konini Elka Grove, recorded in 1939 by the pupils of Turlava Primary School. These relate how, in a grove named Elka, the people of Konini formerly used to worship the pagan gods under the old hollow lime trees. ${ }^{9}$ Although fieldwork has been undertaken by the Archives of Latvian Folklore in Kuldīga District, including Turlava, in later years as well, attention was mainly focused on folk music, giving less attention to legends and stories, and so texts about the Elka Grove were not recorded in the course of this fieldwork. 
Certain interesting evidence regarding Konini Elka Grove found its way into the life stories of the people of the konini villages, recorded in 1996 in the course of the National Oral History Project undertaken by the Institute of Philosophy and Sociology at the University of Latvia:

There was formerly a church on the hill, and whoever died in Konini was taken up to the church. That place is called Elka. ${ }^{10}$

Concerning the Elka Grove, I know only that it was forbidden to touch those trees, otherwise this might lead to a fire or the person might die. Ķonini has already suffered several fires...

And about that cemetery. There was a tradition: after the funeral, everyone drove to the holy grove, and while driving home they broke branches and sang: 'Don't die, you people, there's no more room on the hill [i.e., cemetery]!'11

They waved the branches and said those words. An old lady told that. ${ }^{12}$

In 2006 and 2007, the Faculty of Philology of the University of Latvia, in collaboration with the National Oral History Project, organised a field study in Turlava parish. In the frame of this work, the author conducted a study of legends and stories in Turlava parish connected with specific natural features, including the Konini Elka Grove.

The part of the study relating to Konini Elka Grove included about 30 interviews, mainly with residents of the Turlava area aged between 13 and 85 . The majority of the informants were long-term residents of Turlava parish. A small proportion of the informants were descendents of the koningi families, living in the present day in Ķonini and Turlava, as well as newcomers who had come to live in Turlava during the last couple of decades. Let us consider the main conclusions to be drawn based on the material collected in the course of the field study.

All of the informants living in the vicinity of Konini Elka Grove knew the location of the holy grove. There could be various reasons for this. In the first place, the grove is on a rise and is visible both from Turlava and from Konini; secondly, the Kuldigga-Aizpute highway passes through the grove (Fig. 3); thirdly, since the Elka Grove has been designated an archaeological monument of national importance, it is signposted, although the sign is old and now partly obscured by scrub; fourthly, and probably most importantly, a strong oral tradition continues to exist in the Turlava area, one that has also been adopted by people who have moved to Turlava comparatively recently. The name of the ancient holy forest has also been preserved, since almost all the interviewees 


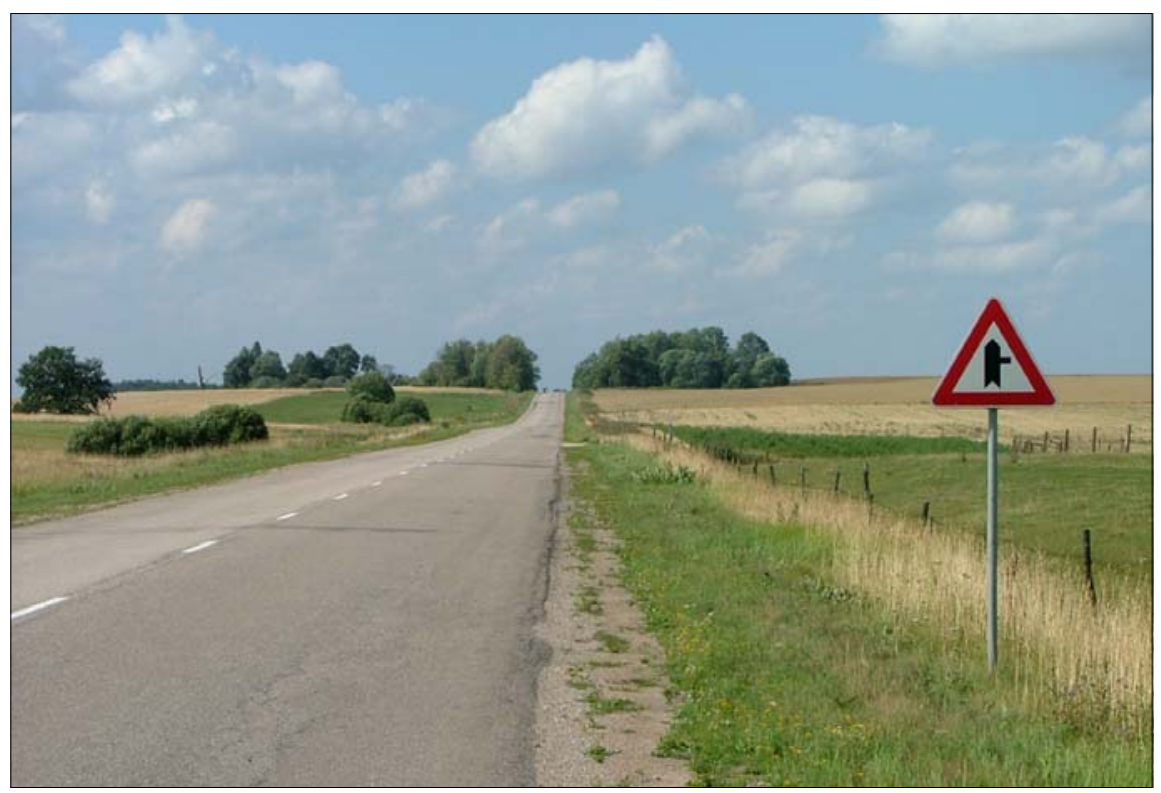

Figure 3. Koningi Elka Grove nowadays. Photo by Sandis Laime (2006).

knew one of the two variants of the name of the holy forest: Elku birzs or simply Elka.

The recorded folklore material about sacred sites in Latvia whose name includes the root $e l k$ - is quite scanty, and nowadays generally the place names alone are preserved, not associated with a major oral tradition. In this regard, Konini Elka Grove is an atypical case, since two thirds of the informants could tell between one and four stories (usually one or two) concerning what had befallen people who had not observed one of the prescriptions regarding behaviour in the Elka Grove. In the Turlava area, the oral tradition not only refers to the same ideas that are recorded in the medieval written sources, but it can also be observed that various accidents and tragic events in the vicinity are regarded as connected with violations of the rules of behaviour in the Elka Grove. Currently circulating are several accounts of events, which have taken on the characteristics of stories and have obtained a stable place in the active repertoire of the informants. In chronological terms, they relate approximately to the past half-century, since the events told as the basis for the belief in the inviolability of the Elka Grove include events that occurred after the Second World War, as well as quite recent occurrences just a few years ago.

At the present day, the residents of the Turlava area mention two prohibitions connected with the Elka Grove: breaking branches in the grove and lighting fires. For the most part, the informants are not only aware of these prohi- 
bitions and the stories about those who violated them, but also strictly observe them. Some of the people interviewed had never even set foot in the Elka Grove, while others considered it permissible to enter the grove, but not to break branches of the trees or light fires. Some typical stories about people who violated the prohibitions:

It is said that one must not enter [the Elka Grove] or pluck anything; otherwise the person will be beset by all sorts of misfortunes. It's also forbidden to light a fire there, otherwise a fire will break out somewhere nearby. And in general it's prohibited to go there for no good reason, just to stroll around. This, too, will result in the person being beset by grave misfortunes. [...] It's true about breaking the branches. My mom told me about a man who lived long, long ago. One of his sheep had strayed into the Elka Grove, and he is said to have broken a branch as a whip to drive the sheep out of the grove, after which he suffered a variety of misfortunes - either his wife or another of his relatives died. He himself also died a cruel death. ${ }^{13}$

It is said to have been a holy place. You were not allowed to cut the trees. If you cut down a tree there, then a fire would start. This is why this village [Konini] has burned down. The last time, a lime tree was cut down there, and a couple of months later several houses burned down over here. ${ }^{14}$

About ten years ago, when the TV people came to Ķonini, on their way back, they lit a fire in the Elka Grove for their film. And at six o'clock next morning, Krukinini [a farm near the Elka Grove] burned down. ${ }^{15}$

When questioned as to the reasons why it was forbidden to break branches or light fires in the Elka Grove, most of the informants asserted that it had been a holy place. Some of the informants pointed out that the Elka Grove was the former site of a church, that is, the concept of a pagan sacred site had been recoded into Christian terminology, which is more comprehensible in the present day. In some cases, the informants asserted that the church in the Elka Grove had existed before the building of Lipaiki Church in Turlava; that at the centre of the grove there had been a stone that served as an altar; that the people of Konini worshipped God by a lime tree with a carved cross. The same process affected other ancient cult sites as well. Thus, several cult hills in Kurzeme are known by the name Baznīcas kalns ('Church Hill'). Archaeological excavation at these sites indicates that they were used for pagan cult purposes. 
Another reason given for the inviolability of the Elka Grove is the former existence of a cemetery in the grove (at the present day there is likewise a proscription against breaking anything in a cemetery or taking anything from a cemetery) or that the dead were formerly cremated here. It seems that the latter explanation has been taken from literature, as has the assertion that the Curonian ksoningi visited the grove only once a year - at Christmas. However, only a small number of such accounts influenced by literature were recorded in the course of the study.

It is possible that the prohibition against lighting fires in the holy grove is a faint memory of the ancient tradition of cremation in the holy groves, since the only legitimate reason for lighting a fire in the grove was connected with the passage of the dead to the next world. Also noteworthy is the account quoted above concerning the only occasion when it was permitted to break branches in the Elka Grove, namely the funerary rites, which were observed as late as at the end of the 19th century, the aim of which, by thrashing each other with sticks from trees in the holy grove, was to avert the approach of death.

In the course of the study, no significant differences were observed, in terms of the stories told and the attitude towards the Elka Grove, between the oldtime residents of Turlava parish and the newcomers of the past decades. Much more typical is a situation when newcomers do not know local folklore at all. Thus, we may conclude that in the case of Turlava, people who became integrated into local society also had to learn the surrounding landscape, including observance of the proscriptions connected with the Elka Grove and respect for the ancient traditions. In this case, the oral tradition connected with the holy grove is more than just "entertaining stories for the long winter evenings". Much more important was the warning that it embodied, since, as the people had a deeply rooted awareness of the inviolability of the Elka Grove, one of the instruments for protecting this site is folklore, which relates how the violation of taboos does not remain unpunished.

The special historically determined status of the Curonian ksoninin has promoted the preservation of many ancient traditions, on account of which these traditions were widely reflected in written sources. Isolation from the peasantry of the surrounding area has promoted the preservation of these traditions and their reflection in the present-day oral tradition. Thus, the material discussed here is a very important starting point for further research on the holy forests of the Courland or Kurzeme region, on Latvia's ancient cult sites in general, and on the regularities influencing the origin and transformation of folklore texts and their continued existence in oral tradition. 


\section{NOTES}

${ }^{1}$ On Lipaiķi Hillfort, see Brastiņš 1923: 95-96.

${ }^{2}$ It is characteristic that near hillforts there are cult sites connected with them, usually 'Elka Hills' (Šturms 1936). Elka kalns, 'Elka Hill', is also a synonym for Ķonini Elka Grove.

3 LFK 1207, 5838 (1939); LVI VK (1972).

${ }^{4}$ LVI VK (1972).

${ }^{5}$ The location of holy forests by river mouths is mentioned as a characteristic feature of the holy forests of Lithuania. See Vaitkevičius 2003: 59.

${ }^{6}$ The scene on the bell-rim has been described in detail by the pastor of Lipaiki Church J. C. Heinsius in 1761 (see http://www.historia.lv/alfabets/K/ku/konini/dok/heinsius/ 1761.11.02.latv.htm; 23.10.2008.)

7 It is significant that the present-day cemeteries of Ķonini, Ziemel̦i and Pliķi are located close to Elka groves. There is an Iron Age cremation cemetery (Birzmalsu senkapi) $\sim 2 \mathrm{~km}$ from the Ķoniņi Elka Grove.

${ }^{8}$ Restriction to a narrow range of possible marriage partners, the people from the kronini families, mentioned in the travel notes of Reinhold Lubenau, was in force right up to the early 20 th century, when marriage to a person who did not belong to the Curonian ksoningi could lead to a serious family conflict.

9 LFK 1207, 4883 (1939); LFK 1207, 4885 (1939).

${ }^{10}$ NMV-390, Otīlija Tontegode-Salmgrieze, 1996.

${ }^{11}$ This is a typical Latvian funeral song (LD 27660 with variants) which was sung after the burial on the way back home from cemetery. Singing was usually supplemented by thrashing each other with the twigs of fir or some other tree.

12 NMV-388, Anna Valija Akota, 1996.

${ }^{13}$ Informant Liene Peniķe (born 1991), Ķoniņi in Turlava parish.

${ }^{14}$ Informant Jēkabs Leimanis (born 1937), Ķoniņi in Turlava parish.

${ }^{15}$ Informant Inita Peniķe (born 1961), Ķoniṇi in Turlava parish.

\section{ABBREVIATIONS}

LD - Barons K., Visendorfs H. Latvju dainas. [Latvian Folksongs.] Jelgava, Pēterburga: Ķeizariskās Zinību akadēmijas spiestava. 1.-6.sēj. 1894.-1915.

LFK - Manuscript archives of the Institute of Literature, Folklore and Art, Archives of Latvian Folklore, University of Latvia.

LVI - Card index of place names of the Institute of Latvian Language, University of Latvia.

NMV - Archives of the National Oral History Project, Institute of Philosophy and Sociology, University of Latvia. 


\section{REFERENCES}

Auns, Muntis 1995. Kuršu ķoniņi. [Curonian Ķoniņi.] In: A. Vītols (ed.) Kurzeme un kurzemnieki. Rīga: Latvijas enciklopēdija, pp. 27-29.

Brastiņš, Ernests 1923. Latvijas pilskalni. Kuršu zeme. [Hillforts of Latvia. Courland.] Rīga: Izdevusi Latvijas Senatnes Petitaju Biedriba "Valodze".

Bušs, Ojārs 2004. Vēlreiz par Valku un valkiem Latvijas toponīmijā. [Once Again about Valka and Valki in Latvian Toponymy.] Onomastika mūsdienu zinātnes skatījumā. Akadēmiķ̌a Jāṇa Endzelīna 131. dzimšanas dienas atceres starptautiskās zinātnisk ās konferences materiāli. Rīga: LU Latviešu valodas institūts.

Dunsdorfs, Edgars 1956. Devin̄vīru spēks: deviņu latviešu vīru dzīves stāsti deviņos Latvijas vestures gadsimtos. [Life Stories of Nine Latvian Men in Nine Centuries of Latvian History.] Stockholm: Daugava.

Dunsdorfs, Edgars (ed.) 1975. Ķoniņu svētie meži. [Sacred Forests of Ķoniņi] Archĩvs: Raksti par latviskām problēmām. Melnburna: PBLA un Kārḷa Zariņa fonds, pp. 43-46.

Dunsdorfs, Edgars \& Spekke, Arnolds 1964. Latvijas vēsture 1500-1600. [History of Latvia 1500-1600.] Stockholm: Daugava.

Kampe, Paulis 1930. Die Kirchenglocken Lettlands von ältester Zeit an bis zum Jahre 1860 und ihre Giesser. Latvijas Ūniversitātes raksti. Architekt ūras fakultātes serija I, 1. Rīga: Latvijas Ūniversitāte, pp. 1-223.

Kurtz, Edith 1924. Verzeichnis alter Kultstätten in Lettland. Mitteilungen aus der Livländischen Geschichte. Vol. 22, No. 2, pp. 47-117.

Mugurēvičs, Ēvalds 1999. Novadu veidošanās un to robežas Latvijas teritorijā (12.gs.16.gs.vidus). [Formation of Districts and Their Borders in the Territory of Latvia (From the 12th Century to the Middle of the 16th Century).] Latvijas zemju robežas 1000 gados. Rīga: Latvijas Vēstures institūta apgāds, pp. 54-90.

Straubergs, Kārlis 1960. Latviešu kultavietu vārdi. [Names of Latvian Cult Places.] In: E. Hauzenberga-Šturma (ed.) In honorem Endzelini. Chicago: Čikāgas baltu filologu kopa, pp. 138-148.

Šturms, Eduards 1936. Elka kalni un pilskalni Kursā. [Elka Hills and Hillforts in Courland.] Pagātne un tagadne. Vēstures skolotāju biedrības rakstu krājums. Rīga: Vēstures skolotāju biedrība, Vol. 1, pp. 82-102.

Šturms, Eduards 1948. Baltu tautu svētmeži. [Sacred Forests of the Balts.] Sauksme Vol. 1/2 (44/45), pp. 17-21.

Švābe, Arveds 1933. Kuršu Ķoniņu un novadnieku tiesiskais stāvoklis. [The Legal Status of Curonian Ķoninni.] Rīgas Latviešu Biedrïbas Zinātņu Komitejas Rakstu krājums. Vol. 21, pp. 23-138.

Švābe, Arveds 1934. Kuršu ķoniṇi. [Curonian Ķoniņi.] Latviešu konversācijas vārdnīca. RīgaGulbis. Vol 10, cols. 19066-19076.

Urtāns, Juris 1993. Latvijas senās svētnīcas. [Ancient Sanctuaries of Latvia.] Rīga: Latvijas enciklopēdija.

Urtāns, Juris 1998. Latvijas seno kulta vietu identifikācija. [Identification of Ancient Cult Sites in Latvia.] Latvijas Vēsture. Vol. 2 (30), pp. 19-24.

Vaitkevičius, Vykintas 2003. Alkai: baltu šventviečiu studija. [The Alkai: Studies into the Balts' Sacred Places.] Vilnius: Diemedis. 